\title{
Features of new sites designing on quarry fields of the existing open pit mines of Kuzbass
}

\author{
Eugene Plotnikov ${ }^{1, *}$, Valery Kolesnikov², Zuzana Šimková ${ }^{3}$, and Nuray Demirel ${ }^{4}$ \\ ${ }^{1}$ JSC Stroyservice, 121 Kuznetsky av., 650055 Kemerovo, Russian Federation \\ ${ }^{2}$ T.F. Gorbachev Kuzbass State Technical University, 28 Vesennyaya st., 650000 Kemerovo, Russian \\ Federation \\ ${ }^{3}$ Technical University in Kosice, Institute of Earth Resources, Faculty of Mining, Ecology, Process \\ Control and Geotechnologies, Park Komenského 19, 042000 Košice, Slovakia \\ ${ }^{4}$ Middle East Technical University, Istanbul, Turkey
}

\begin{abstract}
At a number of large open pit mines in Kuzbass, coal production costs have increased due to the deepening of mining operations. In order to reduce them, separate sections of coal mining at the upper horizons are operating or are being designed for mining at low current stripping ratio. For the same purpose, open-pit mining areas at the fields of existing quarries are operated and designed. Examples of such existing and projected areas are: the "Complex Synclinal" area at the Krasnobrodsky surface mine; the "Prirezka" area at the Chernigovsky surface mine; a number open-pit areas at the underground mines; etc. The main factors complicating the involvement in the development of new sites are: the presence of residential areas, industrial buildings and structures near the boundaries of the mining area; power supply lines, transport communications, which limits or excludes the production of mass explosions in the preparation of overburden for excavation; limited size or lack of areas for external dumps at a short distance from the site (in some cases, it is possible to close the mined-out space of the worked-out quarry field). When designing the development of areas characterized by such conditions, it is necessary to consider the application of new technical and technological solutions.
\end{abstract}

\section{Introduction}

When limiting or excluding the use of mass explosions, it can be orientated to the domestic or foreign equipment that allows digging out strong rocks without blasting. These are, for example, mechanical shovels with buckets equipped with active teeth, or combines of KSM type (Germany).

In case of absence of sufficient areas for external dumps or for the purpose of ground saving it is expedient to consider application of new kinds of mining systems offered by a number of researchers: cross-section continuous, block, step-by-step-deepening or shuttlelayered [1-7].

\footnotetext{
* Corresponding author: plotnikovep@kuzstu.ru
} 
Also it is necessary to note, that a number of new technological decisions on application of the relative new type of the equipment [8-11], namely hydraulic excavators, was studied in a number of works of domestic and foreign scientists [12-27], but these questions were not considered as applied to designing of new sites of open-cast coal mining.

The experience of solving these questions can be traced on the example of the executed project of development of the site "Prirezka", bordering with Novokolbinskoe field on the Chernigovsky open pit.

The section is characterized by high coal content and very complex geological structure (Fig. 1).

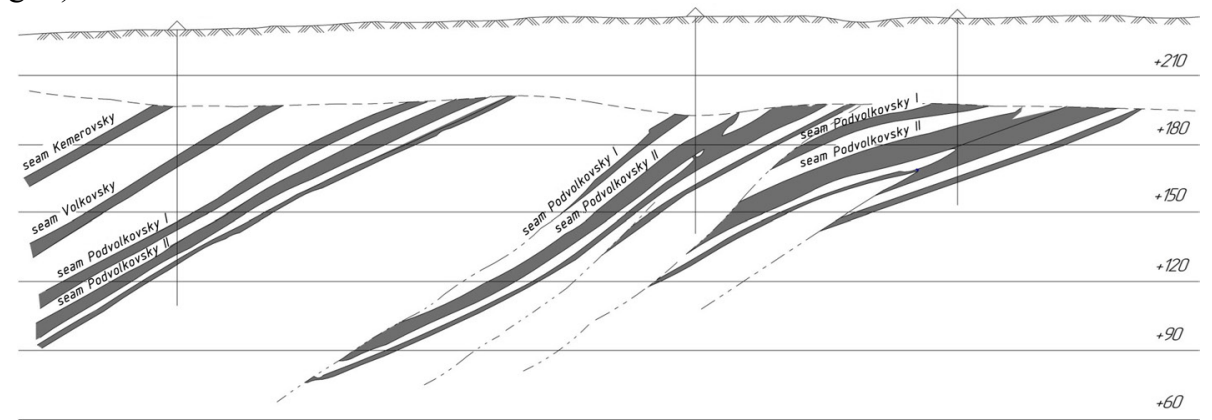

Fig. 1. Geological cross-section along exploration line 7a of the "Prirezka" site.

Coal seams to be work on are Kemerovsky, Volkovsky, Podvolkovsky I and II. The average seam capacity is $8-12 \mathrm{~m}$, with the angle of occurrence varying from $18^{\circ}$ to $30^{\circ}$. The thickness of the quaternary sediments is considerable and varies from $15-40 \mathrm{~m}$. Strength of rocks on the M.M. Protodiakonov scale $\mathrm{f}=3-6$.

The balance reserves of the area are 5.8 million tonnes, while the industrial reserves are 5.4 million tonnes. The reserves have been calculated to the horizon \pm 0 , i.e. to the depth of development of the neighboring Novokolbinskoe field. The boundaries of the area on the surface are: in the north - the sediment yield, in the west - the boundary of Novokolbinskoe field, in the east - the regional highway, in the south - the line of intersection with the day surface of the extinguished side of the area built at an angle of $38^{\circ}$ from the horizon $\pm 0 \mathrm{~m}$. The size of the area: length $1500 \mathrm{~m}$, width $320-700 \mathrm{~m}$.

\section{Materials and Methods}

The design takes into account a number of site features:

- location in close proximity to the northern boundary of the Novokolbinsky power substation area, and along the eastern boundary of the Kemerovo - Anzhero-Sudzhensk regional highway;

- availability of mined-out space, opening mine workings and a transport network away from the western border of the "Prirezka" section built during the mining of the Novokolbinskoe quarry field.

Necessity of consideration of new technological decisions on a way of mining of a quarry field is caused by two factors: value of expenses for moving overburden in a constant dump and requirements of rational land management.

On the analysis of these factors, it is necessary to note the following. On a site at transport delivery of overburden in a dump can be applied only quarry dump trucks because of small stocks of coal and complex occurrence of seams, demanding at their development maneuverable transport. 
In the mined-out area of Novokolbinskoe field it is possible to organize a permanent internal dump for rocks of the Prirezka section. However, the average distance of transportation is large (more than $2 \mathrm{~km}$ ), which limits the volume of expensive trucks overburden. Rational land use requires minimal alienation of land for external dumps.

Placement of an external dump close to a plot contradicts the requirement of rational land use aimed at minimum land alienation.

Thus, when developing a section "Prirezka" overburden should be placed inside the quarry field, with minimum volumes of transportation of overburden to the external dump. Taking into account the dip angles of seams $\left(18-30^{\circ}\right)$, the mining system should be transverse.

\section{Results and Discussion}

The shuttle-layered development system (proposed by NIIOGR Institute) [5, 7] is the most suitable for the conditions of the projected site. This technology does not require creation of the first stage quarry (foundation pit) at the full depth of the site, which causes small construction costs. Besides, limited overburden volumes can be taken out to the mined-out area of Novokolbinskoe field. The main parameters of the shuttle-layer technology are the final depth of the quarry field, determined by the boundary stripping ratio, and the height of horizontal excavation layers [5].

In the initial period the quarry field is developed to the full height of the first (top) layer. In the course of time, if the boundary stripping ratio changes, the depth of the field development can be adjusted [7].

Proceeding from these provisions and taking into account that the final depth of development of the Prirezka section, equal to $200 \mathrm{~m}$, was accepted under the design institute project, the first task of designing was to determine the height of the upper layer.

At consideration of a variant of transport delivery of rocks to the mined-out area of the Novokolbinskoe field the following equipment was accepted: rope shovel EKG-12.5 and dump trucks with carrying capacity of 110 t BelAZ-75191 (preparation of rocks for excavation by a drilling and blasting method is conditionally considered).

For the variant of the transportless technology of the rock excavation on the benches it was accepted rope shovel EKG-5B, and for the re-handling of the rock into the internal dump - dragline ESH 20.90.

According to the generalizing criterion (efficiency impedance) the height of the upper layer is equal to $10 \mathrm{~m}$ for the adopted equipment variants [5].

The established layer height refers only to the bedrocks. It is planned to place unconsolidated quaternary sediments outside the boundary of the site, including in the mined-out area of the Novokolbinskoe field. This decision was made to ensure the stability of the high internal dump.

Development of quaternary sediments is planned to be carried out according to the following scheme. During the construction period for exposure of the area on the rocks necessary for the creation of the foundation pit (pit of the first stage), quaternary sediments along the northern boundary of the site are developed by dragline ESH 11.70 at full thickness (average height of $25 \mathrm{~m}$ ) with the placement of spoil on the mining and nonmining flanks.

In process of development of mining front the quaternary sediments and their spoil on a mining flank will be transported to the worked-out space of Novokolbinskoe field.

The general characteristics of the mining system are as follows. Development of the seventy-meter layer of bedrocks is carried out by 7 benches $10 \mathrm{~m}$ high in accordance with the working parameters of the excavator (Fig. 2). The width of stope is minimum possible 
and equal to $12 \mathrm{~m}$, which is due to the need to drop the rock by rope shovel from the bench to the lower horizon. The development of the benches is done in ascending order.

After dropping the rocks from all the benches, it is handled by the first pass of the dragline into an intermediate spoil 45 meters high. With the second pass the dragline passes the rock to the first tier and with the third - to the second tier of the dump. The height of the first tier is $42 \mathrm{~m}$, which corresponds to the maximum digging depth of ESH 20.90 and the second tier is $38.5 \mathrm{~m}$, i.e. equal to the dragline's unloading height. As a result, an internal dump with a general angle of slope of $27^{\circ}$ and a height of up to $80 \mathrm{~m}$ is formed.

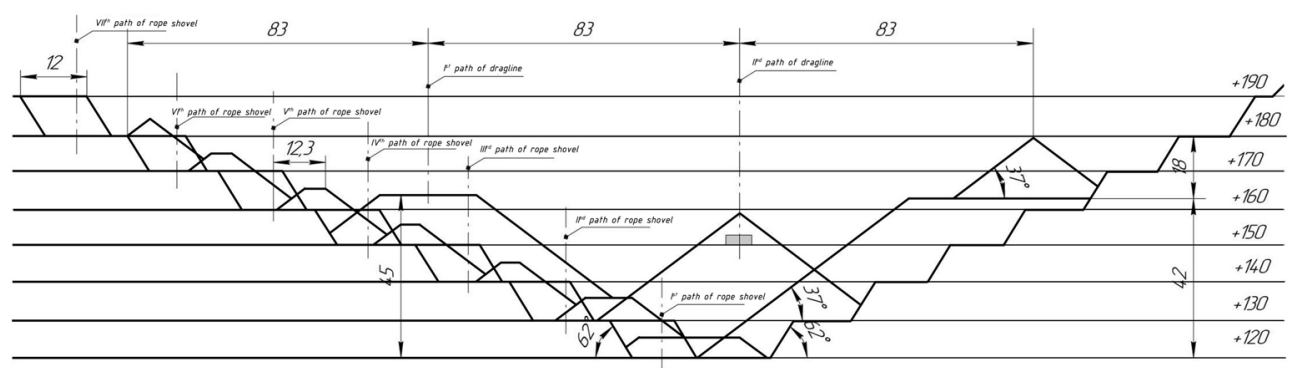

Fig. 2. Profile of the shuttle-layered system for development of the Prirezka section (development of bedrocks and backfilling of the first dump stope).

For coal transportation by dump trucks all horizons (benches) are opened by sliding ramps (temporary trenches). The exit of the route is provided for the horizon $+213 \mathrm{~m}$, where it adjoins the coal road of Novokolbinskoe section. The gradient of the exits is $90 \%$; length is $110 \mathrm{~m}$. Due to constrained conditions, the direction of the ramps at each horizon changes to the opposite. Horizontal junction points with a length of 30 meters are created in this place. The traffic is in a single lane. The width of the carriageway according to the regulations is $7 \mathrm{~m}$, the width of the ramp including the safety berm is $10 \mathrm{~m}$.

For transverse mining systems, which include shuttle-layered, overburden and mining operations alternate as the seam or parting (interbed) is crossed by stope. Therefore, it is not possible to produce standard opened reserves equal to $50 \%$ of annual production capacity for such conditions.

In this case, the mining and construction works for putting the site into operation consist in providing access of excavation and transport equipment to the bedrocks and creation of transport communications.

Construction of the site is completed with an inclined trench on the bedrocks at a horizon of $+190 \mathrm{~m}$, and removal of quaternary sediments in the area of the foundation pit. The total mining and construction volume is 2246 thousand $\mathrm{m}^{3}$, including 906 thousand $\mathrm{m}^{3}$ - spoil re-excavation. With the estimated annual capacity of the dragline ESH 11.70, equal to 2360 thousand $\mathrm{m}^{3}$ by rock mass, and EKG-5B (1264 thousand $\mathrm{m}^{3}$ per year) the construction of the site is carried out in one year.

Mining operations are carried out in three layers $3.3 \mathrm{~m}$ high each, which ensures that the roof of the seam is cleaned and the bottom is dug at an average angle of $30^{\circ}$. The partings with the capacity of up to $90 \mathrm{~m}$ are also mined in three layers, i.e. the entire coal-bearing zone is mined in layers.

For partings extraction usually powerful rope shovels are used to be.

The completed project has shown the possibility to develop local deposits on the area of the developed deposits under the conditions of restrictions on the production of massive explosions with the use of the nearest worked-out mine workings and the available transport network, taking into account the requirements of cost-effectiveness of mining and rational land use. 


\section{References}

1. A.V. Katsubin, A.A. Fedotov, Journal of Mining and Geotechnical Engineering 3(6), 60 (2019). DOI: 10.26730/2618-7434-2019-3-60-75

2. M. Tyulenev, S. Markov, M. Cehlar, S. Zhironkin, M. Gasanov, Acta Montanistica Slovaca 23(4), 368 (2018)

3. S. Markov, J. Janočko, M. Tyulenev, Y. Litvin, E3S Web of Conferences 105, 01021 (2019)

4. O. Litvin, M. Gasanov, S. Zhironkin, M, Tyulenev, Int. J. Of Mining and Mineral Eng. (to be published)

5. A.I. Koryakin, S.M. Fedotenko, A.R. Zhironkin, KuzPI Conference 40, 5 (1990)

6. V.V. Mikhalchenko, S.A. Prokopenko, V.G. Orlov, A.V. Koksin, Ugol' 5, 44 (1991)

7. A.I. Koryakin, KuzPI Conference 44, 49 (1994)

8. M.A. Tyulenev, S.O. Markov, M.A. Gasanov, S.A. Zhironkin, Geotechnical and Geological Engineering 36(5), 2789 (2018)

9. A.V. Strelnikov, Journal of Mining and Geotechnical Engineering 3(6), 4 (2019). DOI: 10.26730/2618-7434-2019-3-4-20

10. A.V. Strelnikov, Journal of Mining and Geotechnical Engineering 4(7), 4 (2019). DOI: 10.26730/2618-7434-2019-4-4-29

11. T. Gvozdkova, S. Markov, N. Demirel, S. Anyona, E3S Web of Conferences 21, 01024 (2017)

12. H. Liu, M. Kearney, M. Forbes, IFAC-PapersOnLine 50(1), 12477 (2017)

13. S. Markov, M. Tyulenev, O. Litvin, E. Tyuleneva, E3S Web of Conferences 15, 01011, (2017)

14. T. Gvozdkova, E. Kuznetsov, A. Rudakova, S. Markov, E3S Web of Conferences 15, 01008, (2017)

15. A. Jessett, Canadian Mining J. 137(7), 30 (2016)

16. M.I. Shchadov, Ugol' 11, 25 (1985)

17. M.M. Bereznyak, A.V. Kalinin, V.G. Pronoza, Soviet Mining Science 6(6), 638 (1970)

18. S. Alarie, M. Gamache, Int J Surf Min, Rec Env 16(1), 59 (2002)

19. E.Y. Baafi, H. Mirabediny, K. Whitchurch, International Journal of Surface Mining, Reclamation and Environment 11, 7 (1997)

20. M. Cehlár, I. Cehlárová, Acta Montanistica Slovaca 12(3), 174 (2007)

21. M. Cehlár, J. Janočko, Z. Šimková, T. Pavlik, E3S Web of Conferences 15, 01019 (2017)

22. E.A. Tyuleneva, Yu.V. Lesin, Ya.O. Litvin, Journal of Mining and Geotechnical Engineering 1(4), 35 (2019). DOI: 10.26730/2618-7434-2019-1-35-49

23. D.M. Dubinkin, V.Yu. Sadovets, G.O. Kotiev, A.V. Kartashov, Journal of Mining and Geotechnical Engineering 4(7), 50 (2019). DOI: 10.26730/2618-7434-2019-4-50-66

24. B. Erdem, N. Çelebi, International Journal of Surface Mining, Reclamation and Environment 12, 189 (1998)

25. D. Hrehová, M. Cehlár, R. Rybár, N. Mitterpachová, Proceedings of 12th Int Multidis Sci GeoConf SGEM2012, 675 (2012)

26. T. Malli, C. Pamukcu, H. Kose, Acta Montanistica Slovaca 20(1), 61 (2015)

27. Z. Šimková, M. Cehlár, H. Pavolová, Acta Montanistica Slovaca 21, 208 (2016) 